\title{
Political Parties and Participative Approaches to Democracy ${ }^{1}$
}

Cristiano Gianolla 


\section{ABSTRACT:}

Representative

democracy is currently facing strong social criticism for its incapacity to involve people in a way that makes them part of the decision-making process An existing gap between the representatives and the represented is hereby emphasized. In this space, the role of political parties is central in order to bridge society with institutions. How much are parties concerned about this issue? How and in which context do they interact more with their electorate and the wider society? Participatory democracy is emerging throughout the world in different forms and with different results, but the dominant pattern of democracy remains the liberal western democratic paradigm in which people can contribute barely through electing candidates.

\section{Introduction}

The Italian constitutionalist Gustavo Zagrebelsky contends that Monti's technical government (nominated by the President of the Italian Republic in 2011 to face the economic crisis) displays the weakness of politics and unfitness of political parties. He stresses the importance of opening up the political sphere to civil society, that is in turn able to challenge the political system; reframing the role of government from a highly centralised decision-making institution to involving citizen participation (Zagrebelsky 2012a). He asserts that we are living in a representative crisis and that political parties need to be renewed and redefined as they are the only political apparatus able to unite society (Zagrebelsky 2012b). Mouffe writes that '[w]hile very few dare to openly challenge the liberal-democratic model, the signs of disaffection with present institutions are becoming widespread.' Traditional parties no longer represent citizens' interests and as a consequence popular adhesion to the values and practices of democracy is on the decline (Mouffe 2000, 80). In response to the instability and unpredictability of 'electoral markets', party leaderships have sought to strengthen the ties between parties thus weakening their relationship with the electors (Mair, Müller, and Plasser 2004).

The representative crisis has resonated strongly in socio-political terms within the western liberal model of representative democracy. Mouffe and Zagrebelsky concentrate on political parties that play a central role in the socio-political dynamics of liberal democracy. Political participation in liberal democracies has been measured using different indicators and approached from different angles; it may include different forms of engagement within the political sphere of which the vote is the foremost recognised and accepted (Parry and Moyser 1994). The representative crisis is related to the participatory deficit that is the reducing of citizens' participation to a matter of electoral contribution (or even just to the vote), as described by Boaventura de Sousa Santos and Leonardo Avritzer (2005). This deficit is evidence that the representative model has neglected its three dimensions: authorisation, identity and accountability (Santos and Avritzer 2005, XLII). That model is propagated and radicalised by technocratic governments and governments controlled by, and in coalition with, representatives of international economic institutions.

Santos and Avritzer list six theses that make it possible to 'widen the democratic canon' beyond the liberal representative model (Santos and Avritzer 2005, 
LXII-LXIX): 1; democratisation of democracy, meaning the creation of equal relations of shared authority not only in the political dimension but also in everyday life; home, work, community, market, citizen-place and at the global level (see also Santos 1995, 417). 2; Demo-diversity; referring to the co-presence of different models of democratic practices beyond the current dominant role of the liberal democratic model. 3; 'Representative democracy tends to be low-intensity democracy' (2005, LXV), characterised by a top-down relation of state-citizens, economic influence over the political sphere and the 'rupture of the relationship between authorization and accountability' (Santos and Avritzer 2005, LXVI). 4; Coexistence and complementarity of representative and participatory democracy, the first representing a limited level of tolerance of participatory practices and the second being a more entrenched link between the two. 5; Articulation of the local and the global to support and strengthen local practices and share their validity in different (local, national, international) contexts. 6; Vigilance against perversion and co-optation (i.e. bureaucratisation, clientelism, technification, manipulation) and continuous self-learning in participatory democracy.

Parties no longer adhere to the will of the people but they still preserve their central role in the functioning of representative democracy (Cuerda 2010,120) in old as in new democracies (Schmitter 2001). It is therefore crucial to investigate what actions they take to enhance participation. Relevant studies on this topic, such as those produced in the 1970-1980s (Olsen 1976; Zipp, Landerman, and Luebke 1982; Marshall 1977), often concentrate on participation internal to political parties such as that of co-workers, volunteers, party members or party leaders. This article has a different aim: to understand how political parties interact within but also outside of their own internal sphere in their attempts to reach people who do not directly engage with party activities. Supported by a literature review and through a comparative analysis, this article highlights possible differences and perspectives in the participation generated by parties, as opposed to participation in civil society and social movements. By focusing on the election period, through the exemplary case of the Italian Five Stars Movement in the city of Carrara, this article provides some insights on how parties can respond to the demand for participation emerging from the bottom-up. This approach seeks to substantiate the thesis proposed by Santos and Avritzer to democratise democracy and increase people's participation, in particular.
In order to achieve what Boaventura de Sousa Santos calls 'democratisation of democracy' the role of political parties is therefore fundamental in particular to achieve a more participative democracy within the representative model. This article approaches this theme through a bibliographic review comparing social movements and political parties with a focus on the innovation of the Five Star Movement in Italy. Finally, it provides a reading of the relationship between political parties and participation, including good practice and perspectives.

\section{KEYWORDS:}

Participation, political parties, social movements, political movements, representative democracy, participatory democracy. 


\section{Thin and Thick Participation}

Participation as a general term is a common concept. In everyday life, people naturally exercise a will to decide on issues relevant for their life. Participation is thus captured as 'action' in Barber's 'strong democracy' (Barber 2003, 122-3) and often emerges from unrest and protest (Sader 2005, 250-2). In the democratic political context, a dualism between different political concepts may lead to a polarisation of participation and, furthermore, produce two forms of participation: thin and thick. This dualism can be understood by adopting a comparison between the liberal and republican models outlined by Habermas (1996a). ${ }^{2}$ In the thin view, participation is fundamentally related to private interactions, including non-institutional business and social dimensions. Here, public decision-making is organised through systems of representation in which the main contribution of the people is expressed through electoral preference (voting). Thin participation is the basic concept of the western liberal democratic paradigm. ${ }^{3}$ The thick view of participation envisages instead fluid public interaction with public institutions, public entities, political parties, etc. It is based on a high level of participation by social groups and individuals affected (or potentially affected) by political decision-making. It is further characterised by the will of the citizen to contribute in a more informed and genuine manner. This is the model shaped by several experiences of participation around the world both in the global South, for instance in Brazil, Colombia, Mozambique, India and South Africa (Santos 2005), and in the Global North, such as in Switzerland, USA, Germany and Italy (Michelotto 2010; Smith 2009). In Habermasian terms, this concept of participation forms the basis of the republican model.

In the thin perspective, the market and informal society are spaces of participation in which people decide for themselves the way they want to live their lives and what environment they opt for - for instance, when they buy goods, when they go on holiday or when they eat out. It is difficult to imagine that people could resign from participating altogether, at least not in decisions that are perceived as directly impacting on one's life. Irreducibly, this perspective relates to the informal social dimension, in which participation primarily concerns social issues of direct interest for the person or people involved. Examples of which are the decisions taken in a residential housing estate or the internal organisation of a sport club or association of any kind. 
There are several common issues, though, that cannot be decided in the informal social dimension, rather, they are required to be discussed more openly and without a restricted list of participants. In the case that they need to be discussed at the formal or institutional (local or not) level, these issues do not necessarily become less important for the individuals involved and affected. Such broader issues may be just as relevant in a private context in having a strong impact on life quality, the respect of personal and collective rights and freedoms, the common use of social and natural resources and so on. A thicker perspective of participation also involves these dimensions.

The liberal democratic model, with its thin participation view, has built a metanarrative of public life in which, due to the complexity of social organisation and administration in modern states, a specialised group of people (political elite) - in its capacity, institutional experience and position - is seen as adequate to deal with socio-political challenges. In this view, the elite can better address the administrative and managerial needs of society for the best interest of the population. Therefore, the most direct action available to citizens is to 'elect' their representatives (at local, regional, national and international level) who would then take care of public affairs on behalf of the whole society. This is also the reason why citizens, in this view, beyond voting, do not need to spend their time and energy in participating in the formal socio-political decision-making process. The thin view expects citizens to believe that the elected representatives are sufficiently competent - or at least to believe that there is no better alternative - in respecting their rights and promoting their interests. Supporters of this position, such as Alessandro Ferrara, consider that representative democracy, although imperfect, is the best result emerging from the democratic evolution over the last two millennia. Representative democracy is thereby professed as an on-going process of constant amelioration. Participatory models, instead, have proven to be unfit for democracy - as in cases like the soviet experience (Ferrara 2012). Participatory practices are considered here as marginal.

The thick conception of participation brings to the debate a wider democratic approach and at the same time a utopian expectation. This is the approach adopted in this article. Two moments associated with this approach can be delineated: in the first, people acknowledge a certain distance from their representatives (as mentioned above) and in the second instant, they hold accountable the elected representatives and contribute to their work either directly or indirectly. It is this second moment which contains a utopian perspective for participation because it 
demands a substantial change of perspective in the liberal representative democratic model. Implementing participatory procedures through and in political parties complies with the first thesis from Santos and Avritzer as already outlined. It implies the 'horizontalisation' of decision-making and enables a plurality of views to come into play in establishing priorities for the political agenda. This means not only a wider consideration of non-traditional domains (home, work, community, market, etc.) in the political forum but also a substantive creation of democratic thinking and education in those non-political domains. It is a democratisation of society and social democracy: "[T]he advent of political democracy preceded the advent of social democracy, if we see politics as the sphere in which the decisions are taken that most affect the community as a whole.' (N. Bobbio 1987, 55)

While the institutionalisation of participatory practices is in initial transition, a thick concept of participation is being developed in societies with irregular and inconstant results, but still in the process of 'democratisation of democracy', as highlighted by Santos and Avritzer. In this phase, society organises itself in parallel to the institutional forms. Nevertheless, this is also the case when parts of society remain silent in the alienation of the predominant (thin) model. Such alienation is a resource sustaining the liberal representative model.

\section{Unpacking Representation and Participatory Approaches}

Participation implies the involvement of individuals or groups in deliberation and decision-making about issues of their concern. Besides the amplitude of the concept (Pitkin 1967), representation is an indirect action in which someone acts, symbolises or talks on behalf of others. The representative must be legitimated and accountable for those actions. The level of representation must be balanced with the need of self-rule (direct decision-making) and personal freedom. 'The effects of an excess of politicization can be that the private sphere reasserts itself' and results in political apathy (N. Bobbio 1987, 56).

The representative should reflect the interests of the people represented. To understand the relationship between participation and representation and the way in which they may co-exist, it is informative to look at Civil Society Organisations $(\mathrm{CSOs})^{4}$ in comparison to political parties. As Bobbio argues 'ascending power, which hitherto was almost entirely confined to the macrocosm of politics at a national level (and to some small, minute, politically irrelevant voluntary associations) is spreading to various spheres of civil society.' (N. Bobbio 1987, 55). 
Newton (1999) elaborates on the difference between social trust (among members of society in the private and social sphere) and political trust (towards political institutions in the public sphere). He argues that these two levels of trust are not causally related and while the former may increase the second may decrease, as in the case of Britain and Sweden (Newton 1999). The dualism between CSOs and political parties, in particular when they acquire parliamentary representation through elections, has been well analysed by Avritzer (2007). He refers to advocacy and electoral forms of representation to identify the representation of ideas and society respectively. In the past, parties embodied ideologies and grouped the people that subscribed to them, a dimension that is increasingly evanescent.

It is assumed that the ethical commitment and participation of members, supporters and followers is the raison d'etre and the functional strength of CSOs. There are three reasons why parties are different from CSOs: first, political parties are political formations claiming to advocate an idea of society and who propose a set of measures to achieve those objectives, although the connection between objectives and actions is blurred; CSOs' objectives are instead generally more targeted and their forms of action more closely correspond with the stated objectives. Second, political parties have an internal structure based on a self-referential membership, that is to say, a party's leadership needs to comply with what its membership demands rather than what the society in general demands (although there must obviously be a connection between the two). ${ }^{5}$ Third, while CSOs are based on a non-profit approach, parties are supported by, and interested in, the management of public funding in order to achieve the individual or social interests officially or unofficially advocated by the party. This implies that the inference of economic objectives on parties' decisions has a relevant impact and that economic objectives therefore compete with those of a social and political nature. While many people identify considerably with global or local $\mathrm{CSOs}^{6}$ advocating ethical causes or specific interests to which they may contribute by volunteering or by supporting their campaigns, political parties on the other hand have lost their capacity to inspire trust among the people - thereby undermining the credibility of the entire political system, especially in the electoral process. $^{7}$

CSOs highly depend on participation; they would not be able to sustain themselves without the support of their members and followers. The majority remain independent from political directions and loyal to the moral or ideological objectives at the core of their statutes (whether formal or informal). This factor makes it easier for people to empathise with CSOs and their work and therefore encourages 
participation. For this reason, CSOs act as a terms of reference in the process of rethinking participation in political parties starting from their bottom-up character. Generally, CSOs are entities born independently from institutions and build an organisational structure conducive to involving people on the base of motivation and trust, contrary to the loss of trust by political parties. In short, CSOs tend to be more transparent, dialogue oriented and open. Political parties, on the contrary, first contract the capacity to genuinely involve people after winning ideological power. Norris $(2011,34-5)$ highlights the erosion of party membership, which is a factor in the fluctuation of electoral choice, on the account of a range of reasons including the will of citizens to choose representatives and programmes and support different parties at different levels (local, national, international). She does not believe that the fall in election turnouts directly represents disaffection with the political system (Norris 2011, 20-1). Evidence from Sweden demonstrates instead a fall in affection with reference to both the political system and party affiliation which results in political distrust (Holmberg 1999). Causes for the distrust can be identified in bad economic and welfare performance, lack of transparency, honesty, competence and social fairness of political leadership. Nevertheless, '[w] hen political parties campaign and try to reach out to people they become more appreciated' (Holmberg 1999, 110).

Participation is not the opposite of representation, rather as seen above, the path to widen the canon of democracy involves complementarity of representation and participation (Santos and Avritzer 2005, LXVI-LXVIII). Moreover, the vote and decisions taken by the majority are not the contrary to participation and indeed, it is wrong to assume that participation does necessarily imply decisions taken by consensus. Once there is an equality of opportunities in participating and clarifying arguments, the vote is the procedural tool that allows a decision to be taken amongst a diversity of opinion (Gbikpi 2005, 111-112). Consensus on decision-making requires a high level of 'symmetry' between positions and their openness (L. Bobbio 2010, 7-9). An experience of coexistence between elections and participation is the case of mayor Pisapia elected in Milan, Italy, in 2012. Social movements emerged to support his campaign and became implementers of participatory consultations after his election (Liso 2012). The adoption of participatory democracy by political parties further signals a step towards realising the fourth thesis by Santos and Avritzer. A complementary form of representative and participatory democracy implies the adoption of participatory democracy in the privileged establishment of representative democracy - that of political parties. 
The kind of participation in the representative arena is 'a complementariness that is necessarily tense but critical as well' (Santos 2006, 42). Bobbio elaborates along the same line although coming from a different angle:

\begin{abstract}
Representative and direct democracy are not two alternative systems, in the sense that where there is one there cannot be the other, but are two systems that can mutually complement each other. One could sum up the situation by saying that in a mature system of democracy both forms of democracy are necessary but they are not, taken on their own, self-sufficient (N. Bobbio 1987, 53).
\end{abstract}

Participation should not become an over-burden or an obligation and indeed participation in social movements is spontaneous. Citizens cannot participate in all matters of public interest: 'For everyone to make decisions on everything in the increasingly complex societies which exist in modern industrial nations is physically impossible' (N. Bobbio 1987, 44; see also Walzer 1992, 92). They have to be able to track the work of their representatives in all those matters which they cannot or do not want to part-take directly, although they are free to use or not the faculty of holding representatives accountable. Nevertheless, there should always be space for citizens to participate in decision-making processes that they feel are close to their needs. This is why participation and representation should be combined trough a deliberative approach (Gutmann and Thompson 2004).

Participation does not exclude perversions per se (i.e. bureaucratisation, clientelism, technification, manipulation) but makes it more complex and extends the breadth of possible actors and mechanisms of vigilance. The first form of vigilance to be reconfirmed (as a guarantee of participatory authenticity) is the transparency, plurality and openness of the deliberative process. A constant vigilance, using the sociology of absences (Santos 2008, 15-29), to identify, and promptly react to any creation of exclusions, has to be applied. Vigilance includes consideration of the context, participants, reflexivity of participants' positions, rules of the debate (L. Bobbio 2010) and, therefore, vigilance against co-optation and manipulation. Transparency, plurality and vigilance are to be hierarchically achieved in this order, although the question of how to accomplish this in practice remains open - also because these mechanisms may be applied through different systems in different contexts. This conceptual framework complies with the sixth thesis of Santos and Avritzer above, vigilance against perversion and co-optation of the political sphere. 


\section{The History of Political Parties and their Comparison with Social Movements}

The work of Donatella Della Porta $(2009,25-42)$ on the history of political parties and their evolution until today will help in understanding the limits of the current form assumed by political parties. Initially, parties were founded and headed by a noble person with considerable social prestige and private funding. This kind of party operated just before the elections and elected representatives worked for the interests of the group of electors. With the growth of democracy, ideological masses emerged together with three other factors: politics became a profession, the party structure became organised and stable and parties became social aggregators (Della Porta 2009, 30). Mass parties were well organised, with wider membership rooted in the territory. Ideology was the element of unity among the numerous party members.

The link between the development of democracy and the meta-construction of parties is very strong. Santos affirms that the strength of representative democracy and in particular the involvement of popular classes, were important achievements in the democratisation process; the perversion occurred when making representative democracy the only form of legitimacy which is monopolised by the most powerful (Santos 2011a, 101). Della Porta confirms that parties were tailored by and, at the same time, shaped the growth of democracy, in particular in circulating democratic values $(2009,36-7)$. The growth of the party membership and the correspondent growing complexity of the organisational structure required a growing number of professionals that produced a systematic bureaucratisation. The leadership became elitist, detached itself from the masses and focused on personal interest and on the party subsistence (as work provider) instead of working to tackle social issues (Della Porta 2009, 61-2). Statistics of the last 60 years show a reduction of the ability of the members to participate in decision-making internal to the party and at the same time the reduction of party membership (Della Porta 2009, 68). In other words, in the western context parties lost credibility, excluded their members from qualitative participation and consequentially lost their own membership due to lack of openness.

Among CSOs, social movements are generally recognised as an example of a bottom-up participatory approach. For instance the indignados or occupy movements are based on participation as they have their origin in the physical and cyber presence of the followers in the squares of the cities and in internet social platforms. Santos (2011b) identifies the objectives of these movements in defence of social welfare, transparency, political as well as socio-economic democracy and 
in the claim of personal and social perspectives that were available to previous generations. They are a manifestation of discontent with democratic institutions. Indignados and occupy are movements that can be inscribed in the new political culture as well as in a different level of personal and social life quality based on democracy, self-governance and participation (Santos 2001, 181). There is a flagrant contrast between the social-interest inspiring participation of social movements and the party-led interest guiding the membership of a party.

Party politics is increasingly professionalised, and party officials accomplish their service in the interest of the party (and their own), as a target-oriented organisation, as well as for the perpetration of the party-based political system. The lack of trust that this view generates towards political parties encourages a bottom-up reactionary approach to politics. This is, most of the time, the space in which political action by social movements takes place (Della Porta 2009, 228). These may be distant or close to the ideology and the political orientation of certain parties. Moreover, political parties can have an interest in supporting the causes of particular social movements (as seen above in the case of Pisapia). Left-wing parties, for instance, are traditionally supportive towards movements advocating social justice (Della Porta 2009, 221-5). At the same time social movements are vigilant and challenging towards all political parties, including left-wing ones. The indignados, for example, have been very critical towards the Spanish left-wing (Pascual 2011). The attentions of parties are frequently perceived as far from the needs the majority of people and too close to institutions; most social movements strongly question this aspect (Della Porta 2009, 207). A widespread demand of social movements is that of participation (Della Porta 2009, 228). This gives validity to the third thesis of Santos and Avritzer, that representative democracy tends to be low intensity democracy. Through participatory practices in political parties, higher intensity forms of democracy would instead privilege horizontal relations between the administrators and the population favouring a constant dialectic between authorisation and accountability and a constant dialogue of consideration, evaluation and affirmation of the conditions under which such a dialectic takes place.

\section{Parties During the Electoral Campaign}

Representative democracy foresees a communicative and participatory relationship between party members and society during the electoral campaign. In this phase, political parties need to stimulate electoral approval and therefore are more open to interaction with citizens in the representative arena. 
Pippa Norris' (2000, 137-161) analytical assessment of pre-modern, modern and post-modern electoral campaigns places the relevance of this moment through a historical perspective. A) Pre-modern campaigns took place in the second half of the $19^{\text {th }}$ and first half of the $20^{\text {th }}$ century. They were supported by partisan media, organised by party leadership and carried out with the direct work of party militants. Party leaders personally met the electorate in campaigning tours and electoral meetings. Pre-modern politics was characterised by mass parties with a consistent membership and campaigns were short and relatively cheap (due to being based on militant work). B) Modern politics and campaigns (mid 1960s, late 1980s) were longer and organised by the top brass of the party with the support of professionals (such as pollsters and media advisers) and by an increased coverage on the broadcast media and thus focused more on the central party leadership. For Norris, in modern politics the electorate was not characterised by mass membership, as in pre-modern politics, rather it was more fluctuant. It means that the competition was stronger among parties to court votes. Personal contacts between candidates and the electorate were limited. Critiques of the lack of participation in the modern campaign lead to post-modern politics. C) Postmodern campaigns collect elements of the pre-modern and modern campaigns. From the pre-modern campaign, they take the interactive approach - this time through new media - and personal engagement and interaction, for instance in electoral meetings. From modern campaigns, they inherit a reduced electorate due to the lack of mass party membership and support of campaign professionals. In post-modern politics, campaigns are permanent and not restricted to the time directly preceding the vote; they are also characterised by high costs with a central organisation led by party leaders in cooperation with professional consultants. The events of the campaign are decentralised and targeted to the electorate at the local level. Post-modern politics use new media for advertisement and also to receive feedback through election polls, thus allowing a higher level of top-down interaction. In her work, Electoral Campaign on the Net, Sara Bentivegna proposes that the concept of post-modern politics and campaigning is characterised by a hegemonic code of belonging to the political community and, further, that such code is identifiable by a wide range of political options combined with an absence of a real possibility to choose (Bentivegna 2006, 25).

The analysis above confirms that the campaign is the window opened by parties to involve the people through more communication and participation even if it is used to manipulate this interaction. Assuming the campaign becomes perma- 
nent, this should lead to a wider space of interaction with political parties and consequently a broader level of participation. However, as argued, a wider range of interaction opportunities is not accompanied by a real choice of possibilities. Thus, alienation is associated with post-modern politics.

Political parties are not using the internet and its potential to take advantage of its participatory potential. They use new media as a hierarchical and centralised organisation for sectorial (not collective) interests and their interaction is not aimed at long-term relations with internet users but a short-term orientation towards the electoral result. Parties' control over communication negates against the campaign being compromised by political communication mistakes (Bentivegna 2006, 38-9). Wide interest has been shown in participating in online political debates especially during campaigning time. Bentivegna (2006, 117-8) partially adopts the term 'cybervolunteering' (Kamarck 2002) to identify the online mobilisation of politically independent individuals generated by an interest in politics. It involves participating in online discussions (by e-mail or other means) with friends or in specific and spontaneous groups independent from political parties. Bentivegna concludes that people are attracted by campaign actions which are not centralised and controlled by parties, but organised in a system that she defines as 'open source' which means spontaneously participated in by volunteers. Once more, political parties face difficulties in dealing with the needs of autonomy of the internet sphere and tend to centralise the campaign $(2006,122)$. In this way, political parties fail to engage with social participation in the most favourable moment provided by liberal democracy (the campaign time) and through in the virtual dimension.

\section{Good Practice to Expand Participation in Electoral Campaigns}

Participation in political parties has been limited to active membership where it, in any case, neither qualifies as quantitative (if compared to the past) nor qualitative participation since decision-making is generally achieved far from the base membership and held by party elites. Encompassing people's interest in their electoral agenda is barely a measurable practice of the political party (Parry and Moyser 1994, 57-8). The participatory approach of the electoral period is a method aimed at acquiring visibility and votes and not at stimulating an open debate on actual social issues. Participation of non-party members is not a priority. Often, as in the case of Portugal, political parties and social movements create what 
Santos calls the 'politically organised civil society' that excludes common people from participating in the political arena. This exclusion questions the way political leaders see (organised) politics and non (-organised) politics (Santos 2011a, 80-1). To make participatory practices in political parties (and the representative arena) effective, the concept of demo-diversity, and the second thesis by Santos and Avritzer, is of fundamental importance. Bringing participation to political parties should lead to the creation of democratic diversification of practices and open up the consideration of alternative models of democratic implementation that are attentive to the diversity present in society. In other words, the scaling down of the representative model, and its combination with an inclusive participatory approach, leads to the acknowledgment and valorisation of social diversity and the diverse richness in the implementation of democracy.

A bridging experience between the organised politics and local population has been implemented by the 'Movimento Cinque Stelle' (M5S), the Five Star Movement in Italy. ${ }^{8}$ M5S does not define itself as a political party preferring instead the definition of political movement, it claims to be keen on social issues and opposes the idea of politicians as a privileged 'caste'. ${ }^{9}$ The M5S has been established since 2009, but its members were active as a social movement under other forms from 2005 when a group of fellows and sympathisers of comedian-activist Beppe Grillo started to be organised around a web-blog and software to create online communities (MeetUp). The 'five Stars' of the movement correspond to its initial main areas of interest: public water, transportation, development (as negative growth), internet connectivity and the environment. It claims to be based on the main concept that 'each one is worth one' and rejects public funding and electoral reimbursement. It asserts to be centred in participatory democracy both as a way of operating and as a way of putting forward public policies. It rejects political elitism by affirming that elected candidates should remain in office for a limited period of time (maximum two mandates). Moreover, they cannot hold more than one public office at a time and their salary is to be determined by means of democratic decision (it should be lower than the current official salary). Finally, M5S candidates must not be members of any political party and have a clean criminal record. The M5S sees politicians as civil servants that should be constantly engaged in talks with the population that they serve; they are not supposed to be professionals of the office they take over as politicians. These and other measures are advocated by the M5S in order to oppose elitist politics and to remain connected with the people and uphold democratic values. The M5S is 
slowly increasing its presence at the local, regional, national and European level. Most importantly, the M5S, even after considering its limitations, has a hybrid identity between a political party and a social movement.

The scheme la parola ai cittadini, was ideated by Paolo Michelotto ${ }^{10}$ and others in 2013, and literally means 'word to the citizens'. The M5S uses this instrument to consult the local population about social issues to be formulated and added in the electoral programme of the M5S. As an example, the M5S section of the city of Carrara (Tuscany) has used this scheme during the months of November and December 2011 in order to consult the population in view of defining the electoral programme in the run up for the administrative elections in May 2012. The initiative took place through seven participatory meetings in different neighbourhoods of the city and with a structured methodology. The meeting duration was fixed to two hours, all speakers had limited amount of time (120 seconds) to propose an idea or issue to be evaluated by the assembly; the assembly could then ask questions (60 seconds each) and the presenter would have a final chance to reply to all the questions (120 seconds). At the end of the meeting the proposals were voted by hand raising and the proposals highest voted were gathered by the M5S for further investigation and possible integration in the electoral programme ('Newsletter Del MoVimento 5 Stelle Di Carrara Numero 2' 2012, 4). The preamble of the electoral programme of the M5S of Carrara confirms that the points gathered in it are the result of the consultations with the population organised in the local territory ('Programma Del Movimento 5 Stelle Carrara 2012' 2012). Elected candidates are available for continuing feedback on their work and the implementation of the programme.

This initiative raises interest because it brings the population closer to the representative political arena allowing an effective participation and constant control over the work of public servants (elected political candidates). The M5S defines this methodology as 'direct democracy' to underline the direct participatory characteristic of common people in the democratic process. Its applicability is valid because it is based on the direct participation made possible by the local dimension of the initiative. The city, as a local dimension, is a privileged scale to give a proportionate reach to participatory democracy, which means that people feel they can and want to intervene because they are interested and affected by issues at this local dimension. Moreover, they see those issues closely enough to see alternative solutions other than solutions offered by the traditional representative political structures. Finally, participation is encouraged by the actual possibility 
of having an impact on common political actions. This is a combination of participatory and representative democracy enhanced by a political party.

The fifth thesis by Santos and Avritzer advocates support for local practices and their escalation to higher levels. Parties find the ideal arena for participatory processes in the local dimension, although this is the first step, not the last objective. The rooting of a participatory responsibility in the society is an exercise of education for the political system administrators and for the citizens from which participation inside the representative arena can also be raised to higher levels such as the regional, national and international (Cuerda 2010). Unveiling the shortcomings of monolithic representative democratic politics leads to a higher demand of participatory approaches by 'political citizens' (Rosales 2010) which is a democratic value not simply related to the local level. The use of the internet and new media to implement participation will support the widening of participatory democracy in the wider context of the representative arena and create a participatory legality. Outside this space it will become harder and harder for the traditional monolithic representative political parties to justify their approach.

\section{Conclusion}

Arblaster explores the history of democracy in the west in the last three centuries and criticises the elitist model inscribed in the centrality of elections, limitation of participation and that is challenged by capitalist exploitation (Arblaster 2002, 37-55). Knowledge systems historically compete with each other, in particular since the colonial predominance of the Western-centric knowledge system which, based on capitalism, has played a dominating role over other cultures and civilisations. Santos, Nunes and Meneses write:

[G]lobal capitalism appears as a civilizational paradigm encompassing all domains of social life. The exclusion, oppression, and discrimination it produces have not only economic, social, and political dimensions but also cultural and epistemological ones (Santos, Nunes, and Meneses 2008, XIX).

This is applicable to the political system and especially to political parties and their history. Della Porta's analysis underlines how political parties have played a historical aggregative role around ethnic, religious, territorial and class identities (Della Porta 2009, 45). For this same reason, they have been shaped by social challenges. During the last two centuries not only political parties but also the 
pattern of ideological validation of party structures have been linked with capitalism. Della Porta, referring to Lipset and Rokkan (1967), identifies two main social fractures that have led to the creation of national political parties as they are: nation state building and industrial capitalism. The second tension is close to the relationship between the company owner or employer and the workers (Della Porta 2009, 45-6). The mass-growth of this problematic led to ideological parties and the strong implementation of the representative functions to the detriment of participatory forms as seen with Santos and Avritzer (2005) above.

This scenario was proven universally invalid, differently than as it was presumed, both in theory and practice. Santos' demo-diversity theory ${ }^{11}$ encourages consideration of a growing number and variety of participatory initiatives, which demonstrate how the practice of representative democracy is being questioned by social movements, and overcome by alternative and complementary democratic practices. ${ }^{12}$ At the theoretical level, additionally, a plurality of frameworks that can be grouped under the deliberative democracy umbrella (Della Porta 2008, 18) have been formulated to reduce the inconsistency of representative democracy.

Parties are still reluctant to take seriously the fact that the expansion of the democratic canon also takes place through their own implementation of participatory (or deliberative) practices. However, the compliance of this hypothesis with the six theses by Santos and Avritzer demonstrates that to undergo a democratisation of democracy, political parties would benefit by expanding their participatory approach. The analysis proposed above explored how this could happen: a thick perspective on participation brings about more horizontality in decision-making and democratisation of agenda settings combined with education to democratic citizenship (thesis 1). Learning from the experience of participatory practices emerging from the civil society, political parties can implement a coexistence of representative and participatory democracy and they pave the way to a complementarity among the two; for this step a constant vigilance against perversion and co-optation is fundamental (theses 4 and 6). Social movements' participatory experience permits to explore paths to reduce the gap between authorisation and accountability. These lessons can benefit political parties in identifying forms to increase the intensity of representative democracy, as explored the case of the M5S (thesis 3). Electoral campaigns are indeed suitable occasions to provide parties with more participatory approaches starting from the local level which, proven successful, bring about scalar applicability of the participatory approach within the party and representative arenas (thesis 5) and openness to a diversified range of 
experiences and practices in the implementation of democratic principles (thesis 2).

Applying the sociology of absences, we can identify a series of exclusions produced by the capitalistic hegemony and now re-emerging from the failure of the representative system. The search for these absences leads to the identification of alternatives - then absences, now emergences (Santos 2008, 29-33). This exercise must start from reconsidering those social transitions that led to the strength of the representative form of democracy and find the alternatives that were not taken into account back then. Most of the absences generated by capitalism are valid and now find fertile ground to flourish. For instance, during the industrial revolution the division between capital and labour aggregated people around the workers parties. Without the intention to question the historical importance of this social fraction and its consequences we now have to consider what alternatives have been silenced because they were considered less urgent than workers' needs at that time. If, in the industrial revolution, there was an urgency and the appropriate sensibility for nature and climate change - as we experience them today - alternative parties would have emerged based on the idea of sharing the Earth; the same goes for human rights, intercultural dialogue and so on. It is possible to imagine that different party ideologies would create different forms of implementing representative forms of democracy. The essential difference of the collective identity and ideology from other party ideologies would have probably produced alternative forms of democratic dominance, including of related party structures. The hegemony of the representative model has created the hegemony of hierarchical party structures and the marginalisation of participatory practices. The awareness that this is not the only possible form of (representative) democracy and the evidence of its limits force us to look beyond representation per se. It includes a search and radicalisation of the alternatives emerging and the imagination of the combination of those alternatives for the establishment of something that does not yet exist but is felt as possible by the simple potential of its existence. Political parties should be aware that the combination of representation and participation is a potential for their development and a form to re-engage their electorate.

Far from the "End of History" announced by Fukuyama (1989) and the supposed maturity of liberal democracy, parties should consider the adoption of the 'ecology of knowledges' (Santos, Nunes, and Meneses 2008, XX), meaning that knowledge that has been marginalised needs to come back into real consideration and presence. This knowledge is with the people; an ecological thinking implies that knowledge and practice, as participation, which were disqualified, become 
plausible again. This knowledge and experience can be reintegrated and translated along with other intercultural knowledge. Scholars, common citizens and social activists have already expressed (in theory and practice) acknowledgment for this urgency. It remains to be observed how promptly the party political system will react in a form that increases participation.

\section{Bibliography}

Arblaster, Anthony. 2002. Democracy. Buckingham UK: Open University Press.

Avritzer, Leonardo. 2007. 'Sociedade Civil, Instituições Participativas E Representação: Da Autorização À Legitimidade Da Ação'. Dados 50 (3): 443-64. doi: 10.1590/S001152582007000300001.

Barber, Benjamin R. 2003. Strong Democracy: Participatory Politics for a New Age. Twentieth Anniversary Edition. Berkeley: University of California Press.

Bentivegna, Sara. 2006. Campagne elettorali in rete. Roma-Bari: Laterza.

Bobbio, Luigi. 2010. 'Types of Deliberation'. Journal of Public Deliberation 6 (2): 1-24.

Bobbio, Norberto. 1987. The Future of Democracy: A Defence of the Rules of the Game. Minneapolis: University of Minnesota Press.

Carbonaro, Mauro. 2013. Grillo Vale Uno. Il Libro Nero Del Movimento 5 Stelle. Roma: Iacobelli.

Cuerda, José Ángel. 2010. ‘¿Partitocracia vs democracia? Apuntes elementales de un exalcalde'. In Crisis de la democracia, edited by Cristina de la Cruz Ayuso and Javier Martínez Contreras, 115-23. Salamanca: Editorial San Esteban.

Della Porta, Donatella. 2008. 'La Partecipazione Nelle Istituzioni: Concettualizzare Gli Esperimenti Di Democrazia Deliberativa E Partecipativa'. Partecipazione E Conflitto, 15-42.

-. 2009. I partiti politici. Bologna: Il Mulino.

Ferrara, Alessandro. 2012. Democracy and Openness. Coimbra, Portugal: Seminar Presentation. Fukuyama, Francis. 1989. 'The End of History'. The National Interest, no. 16 (Summer): 3-18. Gbikpi, Bernard. 2005. 'Dalla Teoria Della Democrazia Partecipativa a Quella Deliberativa: Quali Possibili Continuità?’. Stato E Mercato, no. 1/2005. doi:10.1425/19636.

Gooberman-Hill, Rachael, Jeremy Horwood, and Michael Calnan. 2008. 'Citizens' Juries in Planning Research Priorities: Process, Engagement and Outcome'. Health Expectations 11 (3): 272-81. doi:10.1111/j.1369-7625.2008.00502.x.

Gutmann, Amy, and Dennis Thompson. 2004. Why Deliberative Democracy. Princeton NJ: Princeton University Press.

Habermas, Jürgen. 1996a. 'Three Normative Models of Democracy'. In Democracy and Difference: Contesting the Boundaries of the Political, edited by Seyla Benhabib, 21-30. Princeton NJ: Princeton University Press. 
-. 1996b. Between Facts and Norms: Contributions to a Discourse Theory of Law and Democracy. Translated by William Rehg. Cambridge, MA: MIT.

Hirst, Paul. 1994. Associative Democracy: New Forms of Economic and Social Governance. Cambridge, UK: Polity Press.

Holmberg, Sören. 1999. 'Down and Down We Go: Political Trust in Sweden'. In Critical Citizens : Global Support for Democratic Governance, edited by Pippa Norris, 103-22. Oxford: Oxford University Press.

Kamarck, Elaine Ciulla. 2002. 'Political Campaing on the Internet: Business as Usual'. In Governance.com: Democracy in the Information Age, edited by Elaine Ciulla Kamarck and Joseph S. Nye, 81-103. Washington: Brookings Institution Press.

Lipset, Seymour Martin, and Stein Rokkan. 1967. 'Cleavage Structures, Party Systems, and Voter Alignments'. In Party Systems and Voter Alignments, edited by Seymour Martin Lipset and Rokkan, 1-64. New York: Free Press.

Liso, Oriana. 2012. 'È Stata La Molla Della Vittoria Sarà La Sfida Futura per Pisapia - Milano - Repubblica.it'. La Repubblica, Milano, January 5. http://milano.repubblica.it/cronaca/2012/01/05/news/stata_la_molla_della_vittoria_sar_la_sfida_futura_per_pisapia-27604941/.

Lucía, José Sols. 2010. 'Nuevos agentes en la vida política'. In Crisis de la democracia, edited by Cristina de la Cruz Ayuso and Javier Martínez Contreras, 193-216. Salamanca: Editorial San Esteban.

Luttazzi, Daniele. 2007. 'Il Cosa E Il Come'. MicroMega-, September 12. http://temi.repubblica.it/micromega-online/il-cosa-e-il-come/.

Mair, Peter, Wolfgang C. Müller, and Fritz Plasser. 2004. 'Conclusion: Political Parties in Changing Electoral Markets'. In Political Parties and Electoral Change: Party Responses to Electoral Markets, edited by Peter Mair, Wolfgang C. Müller, and Plasser. London: SAGE.

Marshall, T. 1977. 'Participating in Politics: Do Political Parties Matter?'. Social Science 52 (4): 221-25.

Mello, Federico. 2013. Il lato oscuro delle stelle. La dittatura digitale di Grillo e Casaleggio. Testimonianze, documenti e retroscena inediti. Reggio Emilia: Imprimatur.

Micheletto, Paolo. 2012. 'Dal Seme L'albero: Il m5s E La Democrazia» Democrazia Diretta E Dei Cittadini'. Personal Blog. Il Blog Di Paolo Micheletto - Democrazia Diretta E Dei Cittadini. March 14. http://www.paolomichelotto.it/blog/2012/03/14/dal-seme-lalbero-il-m5se-la-democrazia/.

Michelotto, Paolo. 2010. Democrazia Dei Cittadini. Gli Esempi Reali E Di Successo Dove I Cittadini Decidono. Online available at www.paolomichelotto.it. Vicenza: Troll Libri. http://www.paolomichelotto.it/blog/wp-content/uploads/2010/01/democrazia-dei-cittadini-A4-del-25-01-10.pdf.

Ming, Wu. 2012. 'Appunti Diseguali Sulla Frase «Né Destra, Né Sinistra»'. GIAP. January 2. http://www.wumingfoundation.com/giap/?p=6524.

Mouffe, Chantal. 2000. The Democratic Paradox. London: Verso.

'MoVimento 5 Stelle'. 2012a. MoVimento 5 Stelle. April 9. http://www.beppegrillo.it/movimento/. 
-. 2012b. MoVimento 5 Stelle. April 9. http://www.movimentocinquestelle.it/.

'Newsletter Del MoVimento 5 Stelle Di Carrara Numero 2'. 2012. MoVimento 5 Stelle Carrara. February. http://www.carrara5stelle.it/numero-2.html.

Newton, Kenneth. 1999. 'Social and Political Trust in Established Democracies'. In Critical Citizens: Global Support for Democratic Governance, edited by Pippa Norris, 169-87. Oxford: Oxford University Press.

Non-Statuto - Il Regolamento Del MoVimento a 5 Stelle. 2009. http://www.beppegrillo.it/ iniziative/movimentocinquestelle/Regolamento-Movimento-5-Stelle.pdf.

Norris, Pippa. 2000. A Virtuous Circle: Political Communications in Postindustrial Societies. New York: Cambridge University Press.

-. 2011. Democratic Deficit: Critical Citizens Revisited. Cambridge, UK: Cambridge University Press.

Nylen, William R. 2003. Participatory Democracy versus Elitist Democracy: Lessons from Brazil. New York: Palgrave Macmillan.

Olivetti, Adriano. 2013. Democrazia senza partiti. Roma/Ivrea: Edizioni di Comunità.

Olsen, Marvin E. 1976. 'Three Routes to Political Party Participation'. The Western Political Quarterly 29 (4): 550-62. doi:10.2307/448137.

Parry, Geraint, and George Moyser. 1994. 'More Participation, More Democracy?'. In Defining and Measuring Democracy, edited by David Beetham, 44-62. London: SAGE.

Pascual, José Vicente. 2011. 'Los “indignados”: Termidor de la izquierda?'. Elmanifiesto. com, June 20. http://www.elmanifiesto.com/articulos.asp?idarticulo=3737.

Pitkin, Hanna Fenichel. 1967. The Concept of Representation. Berkeley: University of California Press.

'Programma Del Movimento 5 Stelle Carrara 2012'. 2012. MoVimento 5 Stelle Carrara. April 9. http://www.carrara5stelle.it/programma/carrara-2012/programma-carrara-5-stelle-2012.html.

Rosales, José María. 2010. 'Los Ciudadanos Politicos'. In Crisis de la democracia, edited by Cristina de la Cruz Ayuso and Javier Martínez Contreras, 125-55. Salamanca: Editorial San Esteban.

Rossi, Ernesto. 2012. Contro l'industria dei partiti. Milano: Chiarelettere.

Roßteutscher, Sigrid. 2000. 'Associative Democracy - Fashionable Slogan or Constructive Innovation?'. In Democratic Innovation: Deliberation, Representation and Association, edited by Michael Saward, 172-83. London: Routledge.

Sader, Emir. 2005. 'Toward New Democracies'. In Democratizing Democracy: Beyond the Liberal Democratic Canon, edited by Boaventura de Sousa Santos, 447-68. London: Verso.

Santos, Boaventura de Sousa. 1995. Toward a New Common Sense: Law, Science and Politics in the Paradigmatic Transition. New York: Routledge.

-. 2001. 'Los Nuevos Movimientos Sociales'. Revista Del Observatorio Social de América Latina/OSAL 5 (September): 177-88. 
—., ed. 2005. Democratizing Democracy: Beyond the Liberal Democratic Canon. London: Verso. -. 2006. The Rise of the Global Left, The World Social Forum and Beyond. London: Zed Books. —. 2008. 'The World Social Forum and the Global Left'. Politics \& Society 36 (2): 247-70. doi:10.1177/0032329208316571.

-. 2011a. Portugal - Ensaio Contra a Autoflagelação. 2nd ed. Coimbra: Almedina.

—. 2011b. Las izquierdas europeas tienen que refundarse Interview by Bárbara Schijman. Debate review. http://www.revistadebate.com.ar/2011/07/01/4127.php.

Santos, Boaventura de Sousa, and Leonardo Avritzer. 2005. 'Introduction: Opening up the Canon of Democracy'. In Democratizing Democracy. Beyond the Liberal Democratic Canon, edited by Boaventura de Sousa Santos, 1:XXXIV - LXXIV. London.

Santos, Boaventura de Sousa, João Arriscado Nunes, and Maria Paula G. Meneses. 2008. 'Introduction: Opening up the Canon of Knowledge and Recognition of Difference'. In Another Knowledge Is Possible, edited by Boaventura de Sousa Santos, IX - LXII. London: Verso.

Schmitter, Philippe C. 2001. 'Parties Are Not What They Once Were'. In Political Parties and Democracy, edited by Larry Diamond and Richard Gunther, 67-89. Baltimore and London: JHU Press.

Smith, Graham. 2009. Democratic Innovations: Designing Institutions for Citizen Participation. Cambridge, UK: Cambridge University Press.

Walzer, Michael. 1992. 'The Civil Society Argument'. In Dimensions of Radical Democracy: Pluralism, Citizenship, Community, edited by Chantal Mouffe, 89-107. London: Verso.

Weil, Simone. 1950. 'Note sur la suppression générale des partis politiques'. Table Ronde, no. 26 (February): 9-28.

Zagrebelsky, Gustavo. 2012a. 'Il manifesto di Libertà e Giustizia'. Repubblica.it. http:// www.repubblica.it/politica/2012/02/23/news/il_manifesto_di_libert_e_giustizia-30394025/.

—. 2012b. I partiti devono rinnovarsi altrimenti non c'è democrazia Interview by Goffredo De Marchis. Repubblica.it. http://www.repubblica.it/politica/2012/02/25/news/intervista_zagrebelsky-30468832/.

Zipp, John F., Richard Landerman, and Paul Luebke. 1982. 'Political Parties and Political Participation: A Reexamination of the Standard Socioeconomic Model'. Social Forces 60 (4): 1140-53. doi:10.2307/2577882.

1 This article was developed in the context of the research project «ALICE, strange mirrors, unsuspected lessons», coordinated by Boaventura de Sousa Santos (HYPERLINK "http://alice.ces.uc.pt" alice.ces.uc.pt) at the Centre for Social Studies of the University of Coimbra - Portugal. The project is funded by the European Research Council, 7th Framework Pro-gram of the European Union (FP/2007-2013) / ERC Grant Agreement n. [269807]. Cristiano Gianolla is Phd Candidate at the University of Coimbra and at the University of Rome La Sapienza. 
2 This reference to Habermas does not imply a subscription of his theory but would like to make use of his categorization. Habermas develops a third proceduralist model of democracy base on discourse theory and draws on it his concept of deliberative democracy. Within this model the role of participatory democracy is controversial due to the informality of the discourse and will formation relegated only within civil society and with the power to have an impact on the government only with consultative status and in a crisis stage (Habermas 1996b, 352-379). Citizens Juries are an examples of consultation of this kind (Gooberman-Hill, Horwood, and Calnan 2008, 273).

3 Nylen name 'Elitist Democracy' the current American model based on a thin representation where powerful actors make use of institutions to serve their own interests excluding a considerable part of the population $(2003,4-7)$

4 Lucía (2010) expands the concepts of new agents to: big economic and media groups, popular associations, cultural associations, social movements, NGOs, pressure groups and lobby. Schmitter $(2001,70)$ identifies three intermediaries in Democracies: Political parties, interests associations and social movements. The term CSOs here is used in consonance with 'associative democracy' (Hirst 1994; Roßteutscher 2000) and with special reference to social movements and NGOs.

5 Mair, Müller and Plasser (2004) support the thesis that the power in political parties is more and more centralised in the leadership which does not contradict this point. Indeed the scope of the party is the attainment of internal, as opposed to external, targets.

6 The reference to CSOs is made on a general qualitative intention as a reference to the type of organisations that reflect interests and causes shared by many people on ethical bases, who may or not be directly implied. There is no intention here to make an apology of any sort of CSOs specifically nor to sustain any argument of validity for the aim and actions of transnational Non-Governmental Organisations (NGOs) which may focus on Western-centric concepts and practices risking to clash with cultural diversity requirements and become an instrument for a new form of colonialism.

7 For more considerations about the controversial role of political parties, see Rossi (2012), Olivetti (2013) and Weil (1950).

8 All basic documents of the M5S are available online ('MoVimento 5 Stelle' 2012a; 'MoVimento 5 Stelle' 2012b; Non-Statuto - Il Regolamento Del MoVimento a 5 Stelle 2009). Critical appreciations of the movement are both present online and on printed media (Mello 2013; Carbonaro 2013; Luttazzi 2007).

9 An intense confrontation among M5S fellows, members, sympathisers, supporters and opponents occurred on the blog of Paolo Micheletto (2012). Micheletto maintains that the M5S is a political party lacking internal democracy and under the control of Beppe Grillo and Roberto Casaleggio (its co-founders). Comments to this blog post oppose or uphold this analysis. The discussion unveils a substantial agreement on the fact that beyond some internal limits, among which the lack of internal democracy, the M5S represents an innovative actor in the political arena in Italy. Further critiques are collected in Ming (2012).

10 Michelotto describes the creation of this initiative in the city of Vicenza in 2003 where he was part of the the group 'Gruppo Bilancio Partecipativo' which eventually changed name in 'Comitato Più Democrazia' (Michelotto 2010, 66-70).

11 See also Santos (2008, 266).

12 Representation and participation are at stake in the main popular insurgencies of the current decade, on the one hand to highlight the inconsistency of representation (Indignados and Occupy), on the other hand to request and strengthen the rights and method for being represented (Arab Spring and Umbrella movement). The complementarity between participation and representation emerges as the innovative homogeneity within and beyond liberal democratic regimes. 